\title{
Predicting The Role of Entrepreneur Strategies on Improving Cognitive Positioning in Global Business
}

\author{
A research of leader's opinions in OMV Company in Erbil / Iraq - 2019 \\ ${ }^{1}$ Diyar A. Mustafa Khoshnaw, 2 Ari Adil Hameed \\ ${ }^{1}$ KRG- Ministry of Interior, Erbil Governorate, Kurdistan Region - Iraq \\ ${ }^{2}$ Business administration Lebnanese French University, Kurdistan Region - Iraq
}

\begin{abstract}
The current area characterized with strong competition, the changing pattern of the business, move the value from physicals to knowledges and information, and the shift of the benefits from traditional competition cognitive and intellectual assets, most of the organizations are looking for new methods to achieve a state of leadership and uniqueness in the global market in order to develop the competition.

The current study aimed to identify the role of Entrepreneur Strategies on improving cognitive positioning in the global business area. Moreover, field testing of the views of leaders as a sample of foreign organization operating in Erbil - Iraq, where these dimensions vary in their effects towards the competitive position in global business sector, because of rapid changes in the global business environment as a result of increased competition, as well as the variation of the capacity of the organizations in the adoption of competitive as one of the modern models in the conduct of organizations.

This is why the subject of entrepreneur strategies and cognitive positioning in global business became under the attention of many researchers and scholars being of contemporary themes with impact on the performance of organizations in pursuit of excellence on others, prompting the researcher to choose these subjects to be his field for study.
\end{abstract}

\section{Chapter One: Research Methodology}

\subsection{Research Problem}

The opportunities that exist within the business environment today has become a touchstone of attention of many international companies in different field (industrial, agricultural, tourism, energy and oil wealth) which available in Kurdistan region but it most strong competitive that is why be better if there is strong position in the market, which have an important role to get the opportunities. Can clarify the summarized problem of the study by the following questions:

- How the study sample knows the content of the Entrepreneurs strategies surrounding and influencing on the performance?

- What are the cognitive positions fields in in the company?

- Is there a study sample organizations think that there has a positive role of entrepreneurs strategies factors on the Global business?

\subsection{Research Objective}

The research objective comes from the following questions:

- Does the entrepreneurs strategies in the Kurdistan Region, with all including's varied ingredients, can provide a unique model be able to satisfy the purposes and needs of?

- Does the lack of competitive aware effect to opportunities in Kurdistan region Markets?

\subsection{Research Importance}

The Importance of this study comes from the importance of diagnosis with analysis of global investment factors inherent of foreign companies activities, where alignment with these factors, provide a lot of opportunities to achieve a competitive progress, by familiarity with the number and content of these factors 
in international investment field . It is a strong benefit for organization by the ability to compatibility and harmonizes with all these factors

\subsection{Research Hypothesis}

- There is significant positive relation for entrepreneur strategies on cognitive positioning in global business.

- There is effect relation between entrepreneur strategies on cognitive positioning in global business.

\subsection{Research Methods}

The research applies both the quantitative and qualitative research methods. In this research qualitative method is used because it makes it possible to answer to the questions of questioner. It also applies quantitative because an interview was conducted with the searched company (OMV-Erbil) to explain all items, the Quantitative approach is also equally important as questionnaires and surveys are used to collect the numerical data from employees of the searched firm. Also follow the academic methods to transfer the quantities data to qualitative by Statistical Package for the Social Sciences (SPSS). Moreover, depending on two variables Entrepreneur strategies and independent variables (IV). Also, competitive positioning and dependent variables (DV).

\subsection{Case study}

Case study participated for leaders in searched company. However, topic is hard to understand to all employees in the company; it is for employees who have enough experiences and they can answer this kind of research questioner.

The research took part in the survey is 30 out of which 35 consists of 19 male (69\%) and 11 females (31\%). All participants work at (OMV-Erbil) main branch in which located Erbil, Kurdistan Region of Iraq.
OMV-Erbil established in year 1956 in Austria, but a main branch Kurdistan region in Erbil establish in 2006. Work in energy and power field.

\subsection{Significant (contribution) of the study}

In fact, there is a lack of strategies of entrepreneurship methodologies to improve organizations as a whole. In the case of $\mathrm{OMV}$, accreditation systems and certification schemes, establish criteria to be met, and focus only on part of the organization, and do not include any methodology. There is a need for increasing the positioning to include the organization as a whole, and a methodology to follow. Using the strategies of entrepreneurship should improve the productions of company and services. While, there is strong competition on this service in the world. So, if the company success in its strategies entrepreneurship combines, it leads to improve competitive positioning especially in the global sector.

\subsection{Sample of study}

The study has two variables (Entrepreneur Strategies: Innovation, Creativity, and Risk) as Independent variables, also (Competitive positioning of factors Cost leader, Differentiation, and Alliance) as dependent variables as below: 


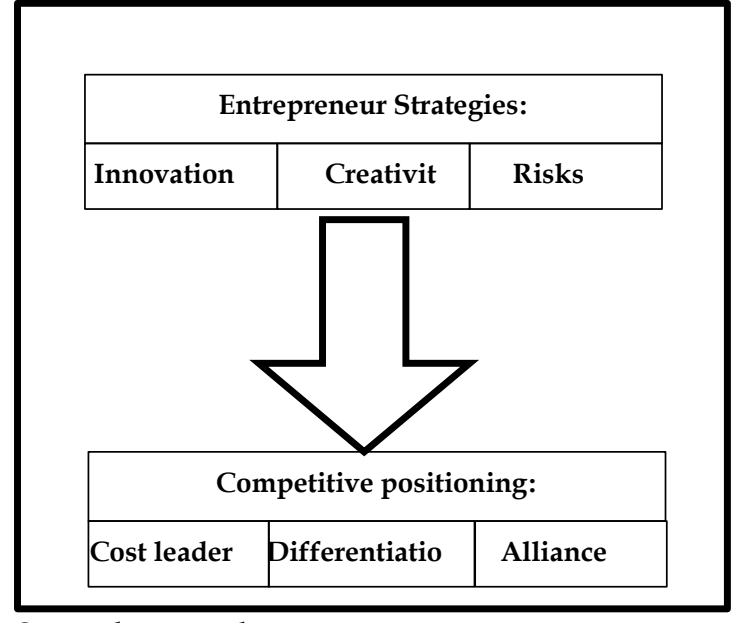

Source: by researchers

Fig. 1. Sample of study

\section{Chapter Two: Theoretical Framework}

\subsection{Entrepreneurs Strategies}

A new competitive landscape developed in the 1990s. Filled with threats to existing patterns of successful competition as well as opportunities to form competitive advantages through innovations that create new industries and markets, this landscape was characterized by substantial and often frame breaking change, a series of temporary, rather than sustainable competitive advantages for individual firms, the criticality of speed in making and implementing strategic decisions, shortened product life cycles, and new forms of competition among global Competitors (Bettis and Hitt, 1995:23).

Strategic entrepreneurship is the integration of entrepreneurial and strategies that create wealth (Hitt et al., 2001). Thus, strategic entrepreneurship is entrepreneurial action that is taken with a strategic perspective. referred to such activity as Romeo (entrepreneur) on the balcony (strategy). Integrating entrepreneurial and strategic actions is necessary for firms to create maximum wealth (Ireland et al., 2001). Entrepreneurial and strategic actions are complementary. The Entrepreneur strategies includes three main strategies that companies can depend on it,
Innovation, Creative and Risk management. (Bettis and Hitt, 1995:59). (Hamel, 2000:66)

\section{A. Innovation}

The essence of entrepreneurship is creation (Lumpkin and Dess, 1996). Innovation, often the foundation of creations, is critical for any firm (large or small) to compete effectively in the twenty-first century's landscape (Hamel, 2000). Building on the importance of entrepreneurial action, Smith and Di Gregorio explain that the essence of entrepreneurship is newness: new resources, new customers, new markets, and/or new combinations of existing resources, customers, or markets.

Furthermore, they differentiate equilibrating and dis equilibrating actions, using the same Austrian framework that served as a basis for many of Alvarez and Barney's arguments. They suggest that equilibrating actions are based on the combination of existing and related resources that revise existing knowledge about markets. In contrast Innovation means Renewal as a rebooting, or new ideas to come in at new product descriptions, new idea and applied (Nolan, R. 1999:71), the innovation means transforming creativity from idea to product,(McDougall, and Oviatt, 2000:90).

\section{B. Creativity}

Mental characteristic that allows a person to think outside of the area, which results in innovative or different approaches to a particular task. amy's creativity is the main factor that landed her the job at the design firm. ( Michael, others: 2002). creating is new knowledge (Ahuja and Lampert, 2013:76). Advantage among entrepreneurial firms engaged in the creation of a new product technology((Van de Ven and Garud, 1993:76)

\section{The Risks}

Taking risk that the launch of new products, considering the risks of a promise to uncertain the market 
environment, (Zahra and Garvis, 2000:61). Meanwhile, the risk associated with a highly uncertain technological advance and where learning distance is quite high. Because learning occurs more efficiently inside an organization (Ahuja and Lampert, 2001:93), also in global business, the risk has strong position considering in entrepreneur process should have taken in all sectors in the market (McGrath,et at,2010:33) as explained in figure (2) below:

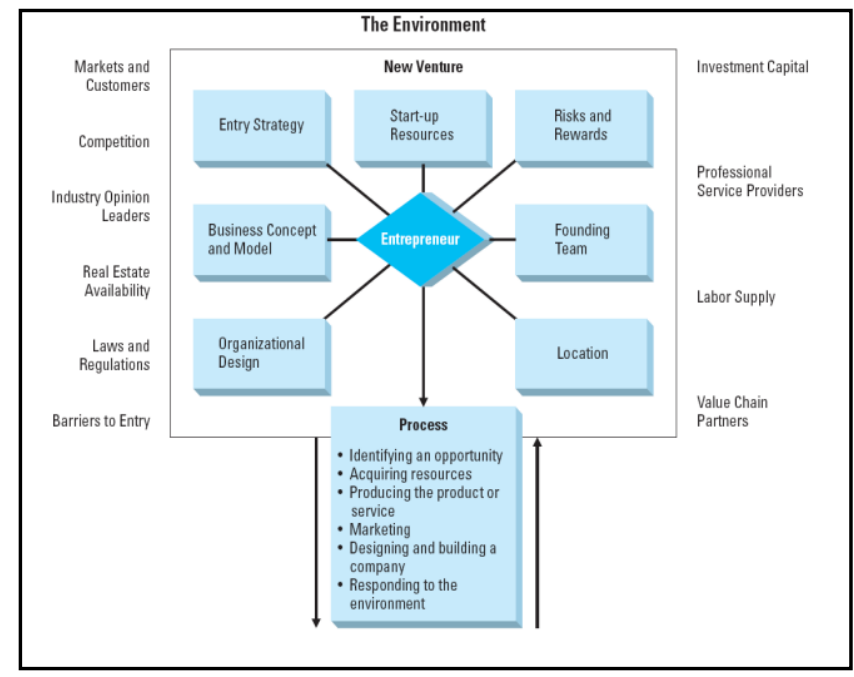

Source: McGrath, R. G. and MacMillan, I. 2000.

Fig. 2. The Entrepreneurship Process

The effective methods to sustain managing the risk statements in uncertain environment, is (SWOT) analysis system, that makes activity on safe side at the global environment factors, to understand the various strength, weakness, opportunities and threats as figure (3).(Guillen, M. F. 2012:65). A process generates right information that is helpful in matching an organization goals, programs, and capacities to the environment in which it operates, both of internal \& external factors environment (Davidsson \& Wiklund, 2010:43)

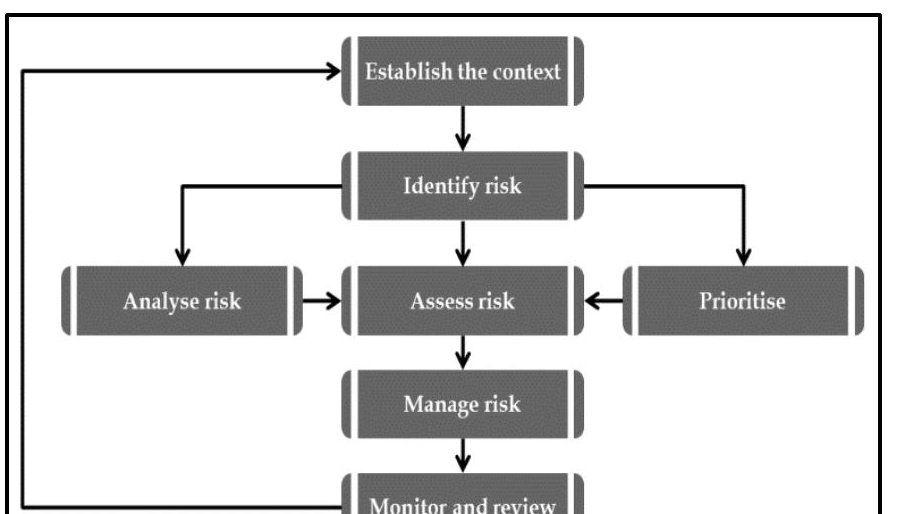

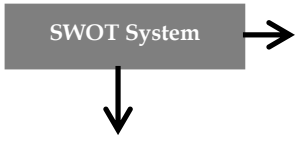

Source: Guillen, M. F. 2012

Fig. 3. Risk Management System

\subsection{Competitive Positioning}

\subsubsection{Cost leader (Driving cost)}

Strategy used by businesses to create a low cost of operation within their niche. The use of this strategy is primarily to gain an advantage over competitors by reducing operation costs below that of others in the same industry. (Bettis and Hitt, 1995). But (Hilman, Mohamed, Othman, \& Uli, 2009:88) stated that to gain cost leadership advantage organization should pursue forward, backward and horizontal integration strategies. Organizations that implement cost leadership strategy employs several activities like accurate demand forecasting, high capacity utilization, economies of scale, technology advancement, outsourcing and learning/experience curve. Cost leadership strategy emphasizes that firms can gain competitive advantage by achieving low cost within the industry.

Also, to producing the better performance based on strategic alignment among organizational strategies approach. The framework is best illustrated through the figure (4).

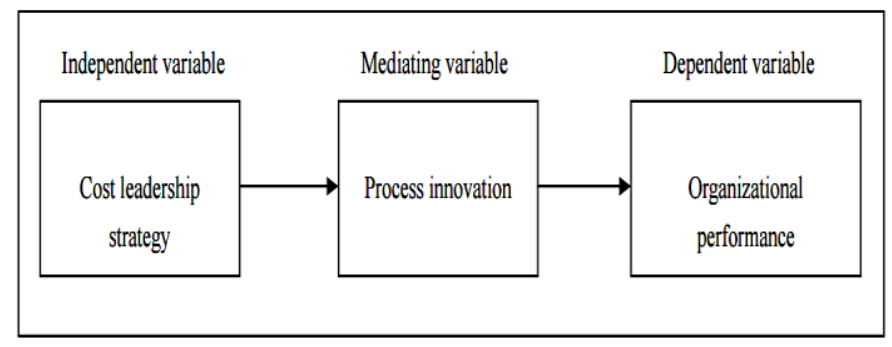

Source: Hilman et.all (2009) 
Fig. 4. Cost leader strategy on organization performance

\subsubsection{Differentiation}

Strategy is based on creating a product or Service at a single or unique of its kind for Customers that are attracted towards the product or service that lead to increased sales (McGrath,et at,2000:109). In traditional strategic analysis, firm's resources are strengths that organizations can use to conceive of and implement their strategies. These resources are broadly categorized into: (Deeds, et all, 2000:122)

- Physical capital resources

- Human capital resources and

- Organizational capital resources

However, (Haml and Prahalad, 1994:33) mentions in global business to complete the strategy missions firm in confusing market in there are three main features of core capability can achieve it:

- The core capability has the full user value, able to create value and reduce costs.

- The core capability is unique, it is difficult to imitate by local and international competitors.

- The core capability must have the ability to provide support for the organization to access a number of markets.

A. The Alliance: While many analysts regard strategic alliances as recent phenomena, inter organizational linkages have existed since the origins of the firm as a production unit. Some examples include firm and entrepreneur ties to credit institutions. Strategic Alliances as Hybrid Forms. Analysts widely recognize that alliances are hybrid organizational forms or hybrid arrangements between firms that blend hierarchical and market elements (Auster \& Olk 2011:186).

\section{Chapter Three: Empirical Study}

\subsection{Describe study Variables}

To explain the number and present of IV variables include $(X 1, X 2, X 4, X 8, X 9$ and $X 10)$ from the questioner the result as Table (1):

The table explains the number and present of each IV variables, it refers to agree with those factors about effect of entrepreneur strategies on Competitive Positioning in Global Businesses. In some factors the entrepreneur strategies brought significant challenges of company to continue in their value in area market.

Table 1

IV variables and standard deviation

\begin{tabular}{|c|c|c|c|c|c|c|c|c|c|c|c|c|}
\hline \multirow[b]{2}{*}{ 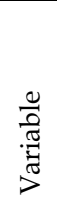 } & \multicolumn{2}{|c|}{$\begin{array}{l}\text { Strong } \\
\text { agree }\end{array}$} & \multicolumn{2}{|c|}{ Agree } & \multicolumn{2}{|c|}{ Neutral } & \multicolumn{2}{|c|}{ Disagree } & \multicolumn{2}{|c|}{$\begin{array}{l}\text { Strong } \\
\text { disagree }\end{array}$} & \multirow[b]{2}{*}{$\stackrel{\Xi}{\stackrel{\Xi}{\Sigma}}$} & \multirow[b]{2}{*}{$\stackrel{\oplus}{\dot{\omega}}$} \\
\hline & $\mathrm{z}$ & $\begin{array}{l}\overrightarrow{\widetilde{D}} \\
\stackrel{D}{0} \\
\stackrel{0}{0}\end{array}$ & Z & 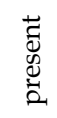 & z & 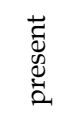 & Z & 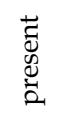 & Z & 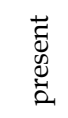 & & \\
\hline $\mathrm{X} 1$ & 20 & 30.8 & 39 & 60.0 & 6 & 9.2 & 0 & 0.0 & 0 & 0.0 & 1.78 & 0.599 \\
\hline $\mathrm{X} 2$ & 16 & 24.6 & 40 & 61.5 & 7 & 10.8 & 2 & 3.1 & 0 & 0.0 & 1.92 & 0.692 \\
\hline X3 & 22 & 33.9 & 30 & 46.2 & 2 & 3.1 & 0 & 0.0 & 0. & 0.00 & 1.48 & 0.612 \\
\hline $\mathrm{X} 4$ & 25 & 38.5 & 30 & 46.2 & 7 & 10.8 & 2 & 3.1 & 1 & 1.5 & 1.83 & 0.858 \\
\hline X5 & 39 & 60.0 & 24 & 36.9 & 2 & 3.1 & 0 & 0.0 & 0 & 0.0 & 1.43 & 0.558 \\
\hline X6 & 28 & 43.1 & 22 & 33.8 & 13 & 20.0 & 2 & 3.1 & 0 & 0.0 & 1.83 & 0.858 \\
\hline X7 & 37 & 56.9 & 27 & 41.5 & 1 & 1.5 & 0 & 0.0 & 0 & 0.0 & 1.48 & 0.612 \\
\hline X8 & 25 & 38.5 .0 & 30 & 46.2 & 2 & 3.1 & 0 & 0.0 & 0 & 0.0 & 1.83 & 0.858 \\
\hline X9 & 37 & 56.9 & 27 & 41.5 & 1 & 1.5 & 0 & 0.0 & 0 & 0.0 & 1.45 & 0.531 \\
\hline X10 & 23 & 34.0 & 31 & 47.6 & 2 & 3.3 & 0 & 0.0 & 0 & 0.0 & 1.50 & 0.643 \\
\hline
\end{tabular}

Source: from researchers

On the other hand, to describe the DV variables in research explained as in Table figure (2).

Table 2

DV variables and standard deviation

\begin{tabular}{|c|c|c|c|c|c|c|c|c|c|c|c|c|}
\hline \multirow{3}{*}{$\begin{array}{l}\frac{0}{0} \\
\cdot \frac{\pi}{\vec{J}} \\
>\end{array}$} & \multicolumn{6}{|c|}{ Strong } & \multicolumn{6}{|c|}{ Strong } \\
\hline & & rree & & gree & $\mathrm{Ne}$ & utral & Dis & agree & dis & Igree & \multirow{2}{*}{$\sum_{\Sigma}^{\Xi}$} & \multirow{2}{*}{$\stackrel{\theta}{\dot{\omega}}$} \\
\hline & 乙 & 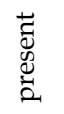 & Z & 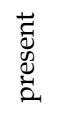 & Z & 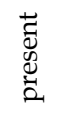 & Z & 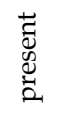 & Z & 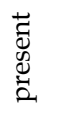 & & \\
\hline $\mathrm{X} 11$ & 34 & 52.3 & 24 & 36.9 & 6 & 92 & 1 & 1.5 & 0 & 0.0 & 1.60 & 0.725 \\
\hline $\mathrm{X} 12$ & 32 & 49.2 & 26 & 40.5 & 7 & 10.8 & 0 & 0.0 & 0 & 0.0 & 1.62 & 0.678 \\
\hline X113 & 3 & 4.6 & 18 & 27.7 & 30 & 46.2 & 11 & 16.9 & 3 & 4.6 & 2.89 & 0.904 \\
\hline X14 & 4 & 4.9 & 24 & 39.9 & 6 & 9.2 & 0 & 0.0 & 0.0 & 0.0 & 1.91 & 0.8 .4 \\
\hline X15 & 26 & 40.0 & 27 & 41.5 & 10 & 15.4 & 2 & 3.1 & 0 & 0.0 & 1.82 & 0.808 \\
\hline
\end{tabular}

\subsection{Analyze correlation and regression}

In first, analyzing the correlation between entrepreneur 
strategies combines including of (Innovation, Creation and Take Risk), on Competitive Positioning in (Cost leader, Differentiation and Alliance) in the global businesses as Table figure (3)

Table 3

Correlation between entrepreneur strategies and Competitive Positioning study

\begin{tabular}{|c|c|c|}
\hline IV & $\begin{array}{c}\text { entrepreneur } \\
\text { strategies }\end{array}$ & Positive Rate \\
\hline $\begin{array}{l}\text { Competitive } \\
\text { Positioning }\end{array}$ & $0.301^{* *}$ & 0.091 \\
\hline
\end{tabular}

Source: from researchers

In the correlation explaining the real relation between both two factors of research its positive relation. Also it measured by $\left(0.301^{* *}\right)$ which support the first assumption:

There is significant positive relation for entrepreneur strategies on competitive position in global business, as explained by results of SPSS program.

Moreover, about the regression relation between the entrepreneur strategies on competitive position in global business as Table figure (4)

Table 4

Regression entrepreneur strategies on competitive position in global business

\begin{tabular}{|c|c|c|c|c|}
\hline \multicolumn{5}{|l|}{ IV } \\
\hline \multicolumn{2}{|l|}{ DV } & \multicolumn{3}{|c|}{ Entrepreneur Strategies } \\
\hline Competitive & B0 & $\mathrm{R}^{2}$ & $\mathrm{~F}$ & Sig \\
\hline Position & 1.999 & 0.051 & 2.999 & 0.089 \\
\hline
\end{tabular}

Source: from researchers

The table demonstrates the positive regression relation and impact of entrepreneur strategies on competitive position in global businesses, that is ensure the second research hypothesis; there is effect relation between entrepreneur strategies on competitive position in global business.

In the results can demonstrate that the relation is positive from the entrepreneur strategies on the competitive position, which is more effect in modern global business, that is the new results and idea that brought from this research. So this result raising the importance of this research to aware all companies for increasing their attentions and depend on more scientific critical methods.

\section{Chapter Four: Conclusions and Suggestions}

\subsection{Suggestions}

- The results of questioner showed the strong relationships between the applications of entrepreneur strategies and achieve competitive advantage for the company researched achieved

- The existence of a positive relationship, and significant elements of moral entrepreneur strategies (Creativity, Innovation, Risk-taking) and achieve competitive advantage for company researched.

- The results of the impact tests, the existence of a direct impact and proportional increasing in the earned achieve competitive advantage as a result of the application of entrepreneur strategies by an increase of $88 \%$ to achieve a competitive advantage in company researched.

- The test explained result of the influence, having a moral and a strong influence in achieving competitive advantage for company researched as the increase by one unit in entrepreneur Strategies variable affects the increase competitive advantage.

- Connectivity and reciprocal relations and moral statistically significant differences between the variable elements of entrepreneur strategies among themselves which (creativity, innovation and risk).

- Relational ties and reciprocal moral and statistically significant among the most variable elements of entrepreneur strategies and the variable elements of competitive advantage with the exception of (taking 
a risk - driving cost) and (taking a risk - alliances) and (innovation - cost) that proved the field study of negative relationships.

\subsection{Recommendations}

- Results of the study highlighted the existence of relations between the entrepreneur strategies, including (creativity, innovation and took a risk) and competitive advantage, (the leadership of cost and differentiation and alliances) so, researcher recommends to companies in trade field, to benefit from the application of the proposed model because of its interest in improving the businesses in Markets.

- The researcher recommends, from the utilization of human resources in terms of creations and innovations have and encourage them to continue the creative work.

- Focus on exclusivity in business through the use of technological equipment as well as human resource development, and this is attracting scientific and technical competencies and specialized methods of selection and recruiting.

- Focus on the development and scientific research in firms, in order to develop the capacities of employees and improve the level of services.

- Focus on proactive and take risks, to seize the opportunities and expansion as well as contract deals between companies and alliances, including helping to provide excellent services for other companies.

- If the companies do not interesting to take the risk and proactive in cost, it has to focus on all the technological and human resources that will be utilized in achieving competitive advantage, and the associated costs in disguise that will help in reducing the costs.

\section{References}

1. Lumpkin, G. T. and Dess, G. G. 1996. Clarifying the entrepreneurial orientation Construct and linking it to performance. Academy of Management Review, (21): 13572.

2. March, J. G. 1991. Exploration and exploitation in organizational learning. Organization Science, (2): 7187

3. Hamel, G. 2000. Leading the revolution. Boston, MA: Harvard Business School Press.

4. Nolan, R. L. 1999. Information technology management from 1960--2000 , Harvard Business School Working Paper: Boston

5. McDougall, P. P. and Oviatt, B. M. 2000. International entrepreneurship: The Intersection of

6. two research paths. Academy of Management Journal, (43): 902 8.

7. McGrath, R. G. and MacMillan, I. 2010. The entrepreneurial mindset. Boston: Harvard Business School Press

8. Michael A. Hitt, R. Duane Ireland, S. Michael Camp And Donald L. Sexton, Strategic Entrepreneurship, 2002.

9. Ahuja, G. and Katila, R. 2013. Technological acquisitions and the innovation performance of acquiring firms: A longitudinal study. Strategic Management Journal, (22): 197220.

10. Van de Ven, A. 1993. The development of an infrastructure for entrepreneurship .Journal of Business Venturing, (8): 21130.

11. Zahra, S. and Bogner, W. 2000. Technology strategy and software new venture.

12. Performance: The moderating effect of the competitive environment. Journal of Business

13. Venturing, (15) (2): 13573.

14. Bettis, R. A. and Hitt, M. A. 1995. The new competitive landscape. Strategic Management Journal, (16) (special issue): 719.

15. Hilman, H., Mohamed, Z. A., Othman, R., \& Uli, J. (2009). The effect of sourcing strategies on the relationship between competitive strategy and firm performance. International Review of Business Research Papers.

16. Deeds, D. L., De Carolis, D., and Coombs, J. (2000). Dynamic capabilities and new product development in high technology ventures: an empirical analysis of new biotechnology firms. Journal of Business Venturing, (15) (3): 21129.

17. Hamel, G. and Prahalad, C. K. 1994. Competing for the future. Boston: Harvard Business School Press.

18. Auster, Ellen R. (2011) ‘Macro and Strategic Perspectives on Interorganizational Linkages: A Comparative Analysis and Review with Suggestions for Reorientation', Advances in Strategic Management, 10B:3-40, JAI Press Inc. 
19. Ireland, R. D., Hitt, M. A., Camp, S. M., and Sexton, D. L. 2001a. Integrating entrepreneurship and strategic management actions to create firm wealth. Academy of Management Executive, (15) (1): 4963.

20. Guillen, M. F. 2012. Business groups in emerging economies: a resource-based view Academy of Management Journal, (43): 36280.

21. Davidsson, P. and Wiklund, J.2010. Conceptual and empirical challenges in the study of firm growth. In D. Sexton and H. Landström (eds), The Blackw ell Handbook of Entrepreneurship. Oxford and Malden, MA: Blackwell , 26 44. 